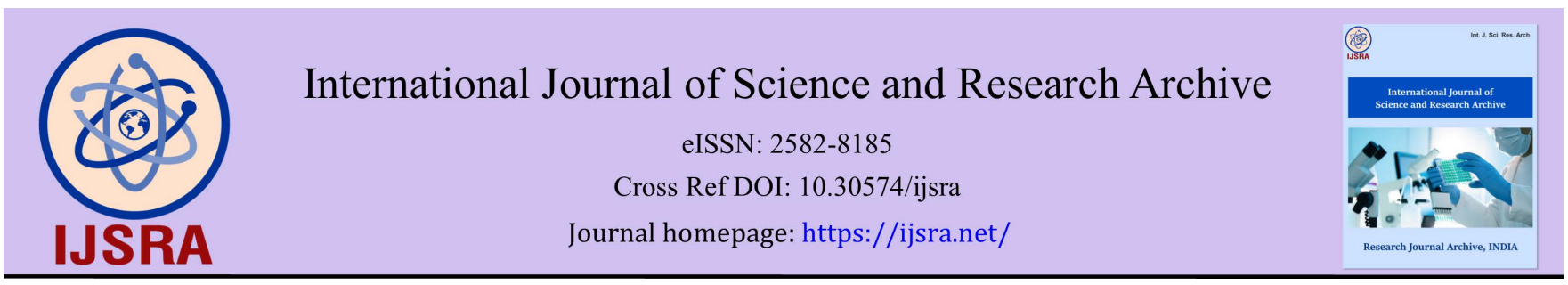

(RESEARCH ARTiClE)

\title{
The effect of combination of AB-mix nutrition with liquid organic fertilizer of tofu liquid waste on hydroponical growth and production of lettage (Lactuca sativa L.)
}

\author{
Arnis En Yulia, Murniati *, Isna Rahma Dini and Laila Manja \\ Department of Agrotechnology, Faculty of Agriculture, Riau University, Indonesia.
}

International Journal of Science and Research Archive, 2021, 04(01), 165-170

Publication history: Received on 13 November 2021; revised on 20 December 2021; accepted on 22 December 2021

Article DOI: https://doi.org/10.30574/ijsra.2021.4.1.0190

\begin{abstract}
This study aims to determine the effect of the combination of $\mathrm{AB}$ mix nutrients with liquid organic fertilizer (LOF) of tofu liquid waste on the growth and yield of lettuce plants and to obtain the best combination for the growth and yield of lettuce hydroponically. This study used a non-factorial Randomized Block Design (RBD), consisting of a comparison of nutritional treatments, namely: $\mathrm{N} 1=100 \% \mathrm{AB}$ mix $+0 \%$ LOF of liquid waste tofu, N2=75\% AB mix $+25 \%$ LOF of tofu liquid waste, $\mathrm{N} 3=50 \% \mathrm{AB}$ mix $+50 \%$ LOF of tofu liquid waste, N4 $=25 \% \mathrm{AB}$ mix $+75 \%$ LOF of tofu liquid waste, N5 $=100 \%$ LOF of waste liquid tofu which consists of 4 replications. Parameters observed were plant height, number of leaves, leaf length, leaf width, root length, fresh weight, root volume and weight fit for consumption. The results showed that the administration of $50 \% \mathrm{AB}$ mix $+50 \%$ LOF of tofu liquid waste and $25 \% \mathrm{AB}$ mix $+75 \%$ LOF of tofu liquid waste showed results that tended to be the same but the results of the combination of $75 \% \mathrm{AB}$ mix $+25 \%$ LOF of tofu liquid waste were higher. On the parameters of the number of leaves is 11.12 strands, fresh weight is $66.40 \mathrm{~g}$ and suitable weight for consumption is $58.31 \mathrm{~g}$.
\end{abstract}

Keywords: AB mix; Tofu liquid waste; Liquid organic fertilizer; Lettuce; Hydroponics

\section{Introduction}

Lettuce (Lactuca sativa L.) is one of the vegetable crops that is quite popular with the community so that it has good prospects for development. The leaves of this plant are consumed in fresh form, can be used as decoration in food dishes or fresh vegetables and as a complement to cooking.

Lettuce provides health benefits because it contains high enough nutrients. The benefits of lettuce for human health are helping the formation of white blood cells and red blood cells, reducing the risk of cancer and cataracts, helping digestion and the health of organs around the liver and eliminating anemia [1].

Lettuce and vegetables are generally cultivated hydroponically because they have a relatively fast harvest life and short roots. Hydroponics is a cultivation system without using soil but utilizing water or water power by using nutrients in dissolved form without land use. Hydroponic cultivation can be done practically, does not need a large yard and the capital is not too large, especially for hydroponic cultivation with a wick system [2].

An important aspect that determines the success of hydroponic cultivation is the nutrient solution. The nutritional needs of plants are met for optimal growth. The plant nutrient solution commonly used in hydroponic cultivation systems is $\mathrm{AB}$ mix which consists of nutrient stock A containing macro elements and stock B containing micro elements.

\footnotetext{
* Corresponding author: Murniati

Department of Agrotechnology, Faculty of Agriculture, Riau University, Indonesia.

Copyright $(2021$ Author(s) retain the copyright of this article. This article is published under the terms of the Creative Commons Attribution Liscense 4.0.
} 
Nutrients for hydroponic cultivation can also be in the form of liquid organic fertilizer. The basic ingredients of liquid organic fertilizer are obtained from household industrial organic wastes, including tofu liquid waste.

The selection of natural materials (tofu liquid waste) is used as an alternative aimed at utilizing waste waste and reducing costs. According to Sutanto [3], organic liquid waste contains nutrients that are useful for plants. Liquid waste can be used directly as fertilizer, both as basic fertilizer and secondary fertilizer. Liquid organic fertilizers (LOF) can also be combined with inorganic fertilizers, this is done with the aim of utilizing waste liquid waste and to reduce costs. [4] Stated that giving LOF of tofu liquid waste with 40\% EM4 produced the highest number of leaves on mustard plants compared to other treatments.

The natural ingredients (liquid tofu waste) used should be accompanied by the use of AB mix fertilizer so that the results obtained are more optimal. The results of the study [5] showed that the administration of AB mix 4 ml..$^{-1}$ water with a combination of $60 \%$ LOF of tofu liquid waste resulted in the best number of fruits per plant in cucumber plants compared to other treatments.

This study aims to determine the effect of the combination of AB mix nutrients with LOF of tofu liquid waste on the growth and yield of lettuce plants and to obtain the best combination of AB mix with LOF of tofu liquid waste for the growth and yield of lettuce hydroponically.

\section{Material and methods}

This research was conducted at the Screen House, Experimental Garden, Faculty of Agriculture, Riau University, Pekanbaru, Indonesia. The research was carried out for 2 months. The materials used in this study included lettuce seeds var. Grand Rapid, AB mix nutrition (good plant), tofu liquid waste, EM4 (decomposer), aquades, pH control solution ( $\mathrm{pH}$ up and $\mathrm{pH}$ down), garlic pesticides, sand, cocopeat, husk charcoal and water. The tools used include the installation of a wick system (plastic tub measuring $40 \mathrm{~cm} \mathrm{x} 30 \mathrm{~cm}$ ), styrofoam, netpot, flannel, table for installation, TDS meter, pH meter, digital scale, measuring cup $20 \mathrm{ml}, 250 \mathrm{ml}$ and $1000 \mathrm{ml}$, ruler, stirrer, $1500 \mathrm{ml}$ mineral water bottle, seedling tray, camera and stationery.

The study was conducted in the form of an experiment consisting of 5 treatments arranged according to a Randomized Block Design (RBD). The treatment was a combination of nutrients consisting of: N1 = $100 \% \mathrm{AB}-\mathrm{mix}+0 \% \mathrm{LOF}$ of tofu liquid waste, $\mathrm{N} 2=75 \% \mathrm{AB}-\mathrm{mix}+25 \% \mathrm{LOF}$ of tofu liquid waste, $\mathrm{N} 3=50 \% \mathrm{AB}-\mathrm{mix}+50 \%$ LOF waste liquid tofu, $\mathrm{N} 4=$ $25 \%$ AB-mix $+75 \%$ LOF of tofu liquid waste, N5 $=100 \%$ LOF of tofu liquid waste $+0 \%$ AB-mix each treatment was repeated 4 times. The data obtained were analyzed statistically using analysis of variance and continued with Duncan's Multiple Range Test at 5\% level. Parameters observed were plant height, number of leaves, leaf length, leaf width, root length, fresh weight, root volume and weight fit for consumption.

\section{Results}

Plant Height and Number of Leaves

The results of variance showed that the use of a combination of $\mathrm{AB}$ mix nutrients with tofu liquid waste organic fertilizer had a significant effect on plant height and number of lettuce leaves. Further test results can be seen in Table 1.

Table 1 Plant height and number of lettuce leaves by giving a combination of nutrients AB mix and tofu liquid waste organic fertilizer

\begin{tabular}{|c|c|c|}
\hline Nutrient Combination AB mix + liquid waste tofu & Height (cm) & Number of Leaves (sheet) \\
\hline $100 \%+0 \%$ & $26,60 \mathrm{a}$ & $11,12 \mathrm{a}$ \\
\hline $75 \%+25 \%$ & $25,11 \mathrm{a}$ & $11,00 \mathrm{a}$ \\
\hline $50 \%+50 \%$ & $24,43 \mathrm{a}$ & $11,00 \mathrm{a}$ \\
\hline $25 \%+75 \%$ & $24,10 \mathrm{a}$ & $10,62 \mathrm{a}$ \\
\hline $0 \%+100 \%$ & $14,80 \mathrm{~b}$ & $7,44 \mathrm{~b}$ \\
\hline
\end{tabular}


The numbers in the column followed by the same lowercase letter were not significantly different according to Duncan's multiple-distance test at the $5 \%$ level.

Table 1 shows that giving $100 \%$ AB mix combined with tofu liquid waste organic fertilizer resulted in plant heights that tended to be the same, ranging from $24.10 \mathrm{~cm}-26.60 \mathrm{~cm}$, but significantly lower with the provision of $100 \%$ nutrition tofu liquid waste organic fertilizer, which was $14.80 \mathrm{~cm}$. The same thing in the number of leaves that with the provision of $100 \% \mathrm{AB}$ mix nutrition and combined with tofu liquid waste organic fertilizer produced the number of leaves ranging from 10.62 to 11.12 strands but significantly lower with the provision of $100 \%$ tofu liquid waste organic fertilizer nutrition, namely 7,44 strands.

\subsubsection{Leaf Length and Leaf Width}

The results of variance showed that the administration of various combinations of AB mix nutrients with LOF of tofu liquid waste on lettuce had a significant effect on leaf length and leaf width. Further test results can be seen in Table 2 .

Table 2 Leaf length and leaf width of lettuce plants by giving a combination of AB mix nutrients and LOF of tofu liquid waste

\begin{tabular}{|c|c|c|}
\hline Nutrient Combination AB mix + liquid waste tofu & Long leaf (cm) & Wide Leaf $(\mathrm{cm})$ \\
\hline $100 \%+0 \%$ & $16,81 \mathrm{a}$ & $14,15 \mathrm{a}$ \\
\hline $75 \%+25 \%$ & $15,55 \mathrm{a}$ & $13,07 \mathrm{a}$ \\
\hline $50 \%+50 \%$ & $15,07 \mathrm{a}$ & $12,65 \mathrm{a}$ \\
\hline $25 \%+75 \%$ & $14,20 \mathrm{a}$ & $12,61 \mathrm{a}$ \\
\hline $0 \%+100 \%$ & $9,80 \mathrm{~b}$ & $8,00 \mathrm{~b}$ \\
\hline
\end{tabular}

The numbers in the column followed by the same lowercase letter were not significantly different according to Duncan's multiple-distance test at the $5 \%$ level.

Table 2 shows that the use of $100 \% \mathrm{AB}$ mix nutrients produces leaf lengths that tend to be the same as the combination of $\mathrm{AB}$ mix + LOF of tofu liquid waste, which ranges from $14.20 \mathrm{~cm}-16.81 \mathrm{~cm}$ but is significantly lower with the use of $100 \%$ liquid waste nutrients organic fertilizer. Know that is $9.80 \mathrm{~cm}$. This is also the same as the results of leaf width, where the use of $100 \% \mathrm{AB}$ mix nutrients produces leaf widths that tend to be the same as the combination of $\mathrm{AB}$ mix + LOF of tofu liquid waste, which ranges from $12.61 \mathrm{~cm}-14.15 \mathrm{~cm}$ but is significantly lower in the use of nutrients. $100 \%$ LOF of tofu liquid waste is $8.00 \mathrm{~cm}$.

\subsubsection{Root Length and Root Volume}

The results of variance showed that the treatment of various combinations of $\mathrm{AB}$ mix nutrients with tofu liquid waste LOF had a significant effect on root length and root volume of lettuce plants. Further test results can be seen in Table 3.

Table 3 Root length and root volume of lettuce plants by giving a combination of AB mix and LOF of tofu liquid waste

\begin{tabular}{|c|c|c|}
\hline Nutrient Combination AB mix + LOF of liquid waste tofu & \multicolumn{1}{c}{ Long root (cm) } & \multicolumn{1}{c}{ Volume Root (ml) } \\
\hline $100 \%+0 \%$ & $23,81 \mathrm{a}$ & $6,00 \mathrm{a}$ \\
\hline $75 \%+25 \%$ & $22,28 \mathrm{a}$ & $6,87 \mathrm{a}$ \\
\hline $50 \%+50 \%$ & $21,84 \mathrm{a}$ & $5,62 \mathrm{a}$ \\
\hline $25 \%+75 \%$ & $19,90 \mathrm{a}$ & $6,87 \mathrm{a}$ \\
\hline $0 \%+100 \%$ & $11,72 \mathrm{~b}$ & $3,37 \mathrm{~b}$ \\
\hline
\end{tabular}

The numbers in the column followed by the same lowercase letter were not significantly different according to Duncan's multiple-distance test at the $5 \%$ level, after being transformed by $\sqrt{y}$ (root volume).

Table 3 shows that the provision of $100 \% \mathrm{AB}$ mix nutrition and various combinations of $\mathrm{AB}$ mix nutrition with LOF of tofu liquid waste resulted in relatively the same root length but higher at the $100 \% \mathrm{AB}$ mix administration, which was 
$23.81 \mathrm{~cm}$ but significantly lower than that given 100 nutrients. \% LOF of tofu liquid waste is $11.72 \mathrm{~cm}$. The same thing with the results of the root volume that the combination of $\mathrm{AB}$ mix nutrients with LOF of tofu liquid waste resulted in a relatively the same root length with the administration of $100 \% \mathrm{AB}$ mix which ranged from $5.62 \mathrm{ml}-6.87 \mathrm{ml}$ but was significantly lower with the administration of $100 \%$ LOF of tofu liquid waste is $3.37 \mathrm{ml}$.

\subsubsection{Fresh Weight and Consumable Weight}

The results of variance showed that the combination of various nutrients $\mathrm{AB}$ mix with LOF of tofu liquid waste on lettuce had a significant effect on the observation of fresh weight and suitable weight for consumption. Further test results can be seen in Table 4.

Table 4 Fresh weight and suitable weight for consumption of lettuce plants by giving a combination of nutrients $\mathrm{AB}$ mix and LOF of tofu liquid waste

\begin{tabular}{|c|c|c|}
\hline \multicolumn{1}{c}{ Nutrient Combination AB mix + LOF of liquid waste tofu } & \multicolumn{1}{c}{ Heavy fresh (g) } & Consumable weight (g) \\
\hline $100 \%+0 \%$ & $58,58 \mathrm{a}$ & $53,27 \mathrm{a}$ \\
\hline $75 \%+25 \%$ & $66,40 \mathrm{a}$ & $58,31 \mathrm{a}$ \\
\hline $50 \%+50 \%$ & $64,10 \mathrm{a}$ & $56,06 \mathrm{a}$ \\
\hline $25 \%+75 \%$ & $64,81 \mathrm{a}$ & $52,39 \mathrm{a}$ \\
\hline $0 \%+100 \%$ & $16,10 \mathrm{~b}$ & $12,52 \mathrm{~b}$ \\
\hline
\end{tabular}

The numbers in the column followed by the same lowercase letter were not significantly different according to Duncan's multiple-distance test at the $5 \%$ level.

Table 4 shows that the nutrition of $100 \% \mathrm{AB}$ mix and combined with LOF of tofu liquid waste produces fresh weight which tends to be the same in the range between $58.58 \mathrm{~g}-64.81 \mathrm{~g}$ but is significantly lower with the provision of $100 \%$ LOF of tofu liquid waste, which is $16,10 \mathrm{~g}$. The same thing with the appropriate weight for consumption, namely the provision of $100 \% \mathrm{AB}$ mix nutrition and combined with LOF of tofu liquid waste produces a suitable weight for consumption which tends to be the same, which ranges from 52.39-58.31 g but is significantly different from the provision of $100 \%$ waste LOF of tofu liquid waste is $12.52 \mathrm{~g}$.

\section{Discussion}

In general, the treatment of $100 \% \mathrm{AB}$ mix, $75 \% \mathrm{AB}$ mix $+25 \%$ LOF of tofu liquid waste, $50 \% \mathrm{AB}$ mix $+50 \% \mathrm{LOF}$ of tofu liquid waste and $25 \% \mathrm{AB}$ mix $+75 \%$ LOF of tofu liquid waste gave results that tended to be the same for all parameters, namely, plant height and number of leaves (Table 1), leaf length and leaf width (Table 2), root length and root volume (Table 3), fresh weight and weight fit for consumption (Table 4) but significantly lower with nutrition $100 \%$ LOF of tofu liquid waste. This is presumably because the $\mathrm{AB}$ mix nutrients and the combination of $\mathrm{AB}$ mix with LOF of tofu liquid waste which are given to lettuce plants hydroponically, are available in the quantities needed by lettuce plants. According to Elisa [6], the level of nutritional needs of each plant in hydroponic cultivation is different. The nutritional requirements for lettuce plants range from 560-840 ppm. Hydroponic nutrients that are commonly used are AB mix, containing macro and micro nutrients needed by plants. Hydroponic techniques are very dependent on the nutrient solution provided. [7] Stated that providing nutrition is very important for plant growth. Provision of nutrients adapted to the type and age of the plant will determine the success of hydroponic cultivation.

The availability of nutrients in sufficient and balanced quantities can greatly affect plant growth. The use of liquid organic fertilizer combined with inorganic fertilizer (AB mix) can complement each other so that it has a good effect on plant growth and yield. The results of the study [8] showed that the substitution treatment of $85 \%$ AB mix with $15 \%$ LOF of rabbit, $70 \% \mathrm{AB}$ mix with $30 \%$ LOF of rabbit and 55\% AB mix with $45 \%$ LOF of rabbit resulted in higher fresh weight consumption (g) in red lettuce compared to with $100 \%$ LOF of rabbit treatment. Research results [9] showed that the $\mathrm{AB}$ mix + LOF of goat manure treatment (3:1) gave the best results and tended to be the same as the $\mathrm{AB}$ mix treatment without LOF of goat manure compared to other treatments on mustard plants.

Lettuce plants have economic value are leaves and the determinant of productivity is weight. The provision of AB mixed nutrition and the combination with LOF of tofu liquid waste had significantly more leaves (Table 1) and significantly heavier plants produced (Table 4) compared to the provision of LOF of tofu liquid waste without AB mix. This is 
presumably because the LOF of tofu liquid waste is low so that with the addition of AB mix nutrients the growth and development of lettuce plants is better. According to Tiendapati [10], the nutrients that are commonly given to plants that are cultivated hydroponically are $\mathrm{AB}$ mix but can also be in the form of LOF. Research results [11] showed that the substitution of $25 \%$ liquid organic fertilizer in $\mathrm{AB}$ mix nutrition gave the best results on plant height, number of leaves, leaf width and fresh weight of caisim plants compared to other treatments.

The number and size of leaves greatly determine the results of photosynthesis which affect the growth and development of plants. More number of leaves and larger size resulted in an increase in the rate of photosynthesis. This resulted in an increase in photosynthate produced and translocated to all plant organs which was also seen in root growth (Table 3 ) in the administration of $75 \%, 50 \%$ and $25 \% \mathrm{AB}$ mix nutrients combined with $25 \%, 50 \%$ and $75 \%$ LOF. Tofu ranged from $19.90 \mathrm{~cm}-23.81 \mathrm{~cm}$ for root length and $5.62 \mathrm{ml}-6.87 \mathrm{ml}$ for root volume.

Longer roots and larger volumes indicate a better root system and also have a greater ability to absorb nutrients. Root length and root volume (Table 3) are important factors in plant growth because roots reflect the ability to absorb nutrients used by plants for photosynthesis. [12] Stated that the photosynthesis process is influenced by the speed of nutrient absorption from the roots to the plant, increasing photosynthesis will increase the photosynthate produced, so that translocation to plant organs such as leaves runs optimally and can increase plant fresh weight.

The number and size of leaves greatly determine the results of photosynthesis which affect the growth and development of plants. More number of leaves and larger size resulted in an increase in the rate of photosynthesis. This resulted in an increase in photosynthate produced and translocated to all plant organs which was also seen in root growth (Table 3 ) in the administration of $75 \%, 50 \%$ and $25 \% \mathrm{AB}$ mix nutrients combined with $25 \%, 50 \%$ and $75 \%$ LOF. Tofu ranged from $19.90 \mathrm{~cm}-23.81 \mathrm{~cm}$ for root length and $5.62 \mathrm{ml}-6.87 \mathrm{ml}$ for root volume.

Longer roots and larger volumes indicate a better root system and also have a greater ability to absorb nutrients. Root length and root volume (Table 3) are important factors in plant growth because roots reflect the ability to absorb nutrients used by plants for photosynthesis. [12] Stated that the photosynthesis process is influenced by the speed of nutrient absorption from the roots to the plant, increasing photosynthesis will increase the photosynthate produced, so that translocation to plant organs such as leaves runs optimally and can increase plant fresh weight.

Lettuce plants that received $100 \%$ LOF of tofu liquid waste treatment at the same concentration as other treatments gave the lowest yields on all parameters. It is suspected that the LOF of tofu liquid waste treatment without the addition of $\mathrm{AB}$ mix nutrients has not provided nutrients in sufficient quantities to meet plant needs. The nutrient content in the LOF of tofu liquid waste is low as stated by [4] that the LOF of tofu liquid waste contains a total of $1.16 \% \mathrm{~N}$ nutrients, $0.04 \% \mathrm{P}$ and $1.137 \% \mathrm{~K}$ and $5.803 \%$ C-Organic.

The low level of nutrients in the LOF nutrition of tofu liquid waste causes plant growth to be inhibited in all parameters. If the nutrient content in plants is not yet available in sufficient quantities, the rate of photosynthesis will be slow so that less photosynthate is produced and the plants produced are also low. According to Musnamar [13], nutrient deficiency affects plant growth. Plants that lack nutrients will inhibit enzyme activity so that they cannot grow properly and plants will grow stunted and small leaves are formed. The results of the study [14] showed that the provision of LOF of paitan nutrition and cow dung LOF without $\mathrm{AB}$ mix obtained results that were relatively low compared to $\mathrm{AB}$ mix nutrition which was able to increase root length, stem diameter, plant fresh weight and edible weight of plants on kailan plants.

\section{Conclusion}

The results of the research on the effect of the combination of $\mathrm{AB}$ mix nutrients with tofu liquid waste organic fertilizer on the growth and yield of hydroponic lettuce plants that have been carried out, it can be concluded that:

- The combination of $\mathrm{AB}$ mix nutrition with tofu liquid waste organic fertilizer significantly affected all observation parameters, namely: plant height, number of leaves, leaf length, leaf width, root length, fresh weight, root volume and weight fit for consumption.

- Giving nutrition $100 \% \mathrm{AB}$ mix, a combination of $75 \% \mathrm{AB}$ mix $+25 \% \mathrm{LOF}$ of tofu liquid waste, $50 \% \mathrm{AB}$ mix + $50 \%$ LOF of tofu liquid waste and $75 \% \mathrm{AB}$ mix $+25 \%$ tofu liquid waste organic fertilizer, resulting in plant height, number of leaves, leaf length, leaf width, root length, fresh weight, root volume and weight fit for consumption which tend to be the same. 


\section{Compliance with ethical standards}

\section{Acknowledgments}

The author would like to thank all the authors who were involved in the research and compiled the results of this research.

\section{Disclosure of conflict of interest}

All authors declare there is no conflict of interest in this paper.

\section{References}

[1] Cahyono. Budidaya Tanaman Sayuran [Vegetable Cultivation]. Penebar Swadaya. Jakarta. 2005.

[2] Anonim. Pedoman Budidaya secara Hidroponik [Hydroponic Cultivation Guidelines]. Nuansa Aulia. Bandung. 2010.

[3] Sutanto R. Penerapan Pertanian Organic Promotional and Pengembangan [Application of Correctional and Developmental Organic Agriculture]. Kanisius. Yogyakarta. 2002.

[4] Sutrisno A, R Evie, F Herlina. Fermentasi limbah cair tahu menggunakan Effective Microorganism (EM4) sebagai alternatif nutrisi hydroponik and application pada sawi hijau [Fermentation of tofu liquid waste using Effective Microorganisms (EM4) as an alternative to hydroponic nutrition and its application to. J. of Lentera Bio. 2014; 4 (1): 21-27.

[5] Zary R, Q Islan, AEYulia. Pemanfaatan limbah cair tahu dan nutrisi AB mix sebagai nutrisi tanaman mentimun (Cucumis sativa L.) by hydroponics [Zary, R, Q., Islan, and A. E. Yulia. 2018. Utilization of tofu liquid waste and AB mix nutrients as hydroponic nutrition for cucumber (Cucumis sativa L.)]. J. Online Student Agriculture Faculty. 2018; 5 (2): 12-13.

[6] Elisa. Panduan Lengkap and Praktis Budidaya Hydroponic yang Paling Menguntungkan [Complete and Practical Guide to the Most Profitable Hydroponic Cultivation]. Garuda Pustaka. Jakarta. 2018.

[7] Moesa Z. Hydroponic Creative Membangun Installation Unik Menggunakan Barang Bekas [Creative Hydroponics Build Unique Installations Using Used Items]. Agromedia Pustaka. Jakarta. 2016.

[8] Hambali PF, WE Murdiono, Koesrihar. Pengaruh substitusi ab mix with pupuk organic cair kelinci pada pertumbuhan dan hasil tanaman selada merah (Lactuca sativa L.) with system rakit apung [Effect of substitution of ab mix with rabbit liquid organic fertilizer on growth and yield of red lettuce (Lactuca sativa L.). ) with floating raft system]. J. Produksi Tanaman. 2018; 6 (12): 3096-3105.

[9] Purwanto E, Y Sunaryo, S Widata. Pengaruh combinasi pupuk AB mix and pupuk organic cair (POC) kotoran kambing terhadap pertumbuhan dan hasil sawi (Brassica juncea L.) hydroponic [The effect of the combination of $\mathrm{AB}$ mix fertilizer and liquid organic fertilizer of goat manure on the growth and yield of hydroponic mustard greens (Brassica juncea L.)]. J. of Educational Evaluation Studies (JEES). 2018; 2 (1): 35-54.

[10] Tjendapati C. Bertanam Sayuran Hydroponic Organic with Nutrisi Alami [Growing Organic Hydroponic Vegetables with Natural Nutrients]. Agromedia Pustaka. Jakarta. 2017.

[11] Marginingsih SR, AS Nugroho MA Dzakiy. Pengaruh substitusi pupuk organik cair pada nutrisi AB mix terhadap pertumbuhan caisim (Brassica juncea L.) pada hydroponic drip irrigation system [Effect of liquid organic fertilizer substitution on $\mathrm{AB}$ mix nutrition on the growth of caisim (Brassica juncea L.) in a hydroponic drip irrigation system]. Journal of Biology and Journalism. 2017; 5 (1): 44-51.

[12] Gardner FP, RB Pearce, RL Mitchel. Physiology of Crop Plant. Translated by Herawati Susilo. Physiology Tanaman Budidaya. UI Press. Jakarta. 1991.

[13] Musnamar EI. Pupuk Organik [Organic fertilizer]. Penebar Swadaya. Jakarta. 2007.

[14] Abdillah BS, A Nurul, H Didik. Pengaruh pemberian pupuk cair paitan dan kotoran sabigai nutrisi tanaman kailan (Brassica oleraceae var. Alboglabra) dalam sistem hiroponik [effect of paitan liquid fertilizer and cow dung as nutrients for kailan (Brassica oleraceae var. J. Produksi Tanaman. 2017; 5 (9): 1533-1540. 